\title{
Inoperable Pancreatic Metastasis of Renal Cell Carcinoma: A Case Report and a Review of Literature
}

\author{
Hanae Bedoudou1*, Lamiae Boudahna1, Adil Mai², Boubacar Efared ${ }^{3}$, Said Ait Laalim4, \\ Laila Chbani ${ }^{3}$, Youssef Alaoui Lamrani' ${ }^{2}$, Nawfel Mellas ${ }^{1}$
}

${ }^{1}$ Medical Oncology Department, University Hospital Hassan II, Fez, Morocco

${ }^{2}$ Radiology Department, University Hospital Hassan II, Fez, Morocco

${ }^{3}$ Anatomical Pathology and Cytology Laboratory, University Hospital Hassan II, Fez, Morocco

${ }^{4}$ General Surgery Department, University Hospital Hassan II, Fez, Morocco

Email: ^hanae.bedoudou@usmba.ac.ma

How to cite this paper: Bedoudou, H., Boudahna, L., Mai, A., Efared, B., Laalim, S.A., Chbani, L., Lamrani, Y.A. and Mellas, N. (2017) Inoperable Pancreatic Metastasis of Renal Cell Carcinoma: A Case Report and a Review of Literature. Journal of Cancer Therapy, 8, 168-172.

https://doi.org/10.4236/jct.2017.82014

Received: January 10, 2017

Accepted: February 11, 2017

Published: February 14, 2017

Copyright $\odot 2017$ by authors and Scientific Research Publishing Inc. This work is licensed under the Creative Commons Attribution International License (CC BY 4.0).

http://creativecommons.org/licenses/by/4.0/

\begin{abstract}
Renal cell carcinoma (RCC) is a common cancer, but its pancreatic metastasis is unusual. We report a case of a 50-year-old male who was under the first line of treatment for a metastatic RCC since 2009. In August 2015, he showed up to the day unit with a cholestatic jaundice, and the investigations led to the discovery of a liver function alteration and a pancreatic mass. The biopsy of the inoperable mass revealed a RCC metastasis. The localization of this metastasis complicated the management of the disease due to haemorrhage and anemia. An embolization was performed to control the local complications. The patient was commenced on everolimus but with modest results forcing us to start exclusive palliative care.
\end{abstract}

\section{Keywords}

Renal Cell Carcinoma, Biopsy, Pancreatic Metastasis, Inoperable, Everolimus

\section{Introduction}

Renal cell carcinoma (RCC) is the second most common urological malignancy, running a highly variable clinical course [1]. Among patients with RCC, $20 \%$ $30 \%$ have metastases at presentation and up to $40 \%-50 \%$ develop widespread metastatic disease after nephrectomy. The pancreas is an uncommon location for metastases, which accounts for less than $5 \%$ of all pancreatic malignancies [2] [3]. A variety of cancers have been shown to metastasize in the pancreas, such as colon cancer, non-small cell lung cancer, and melanoma. RCC in particular shows, besides metastases to lymph nodes, lung, liver and bones, an in- 
creased disposition for metastasis in rare sites, such as the thyroid gland and the pancreas [4] [5].

\section{Case Report}

A 50-year-old male (Table 1) with a background of obesity developed a left sided renal cell carcinoma in 2008. He underwent a radical nephrectomy. Pathological staging concluded to a pT4, Fuhrman Grade 4 clear cell type tumor. There was no evidence of metastatic disease at that time and he was placed under surveillance. In February 2009, he developed pulmonary and bone metastases. The patient underwent a treatment based on Sunitinib plus zoledronic acid. After 24 months of treatment (interspersed with treatment breaks), the patient's disease was stable.

In August 2015, he showed up to the Day Unit with a week history of jaundice and pruritus as PS 2 patient. Liver function tests were grossly abnormal with a cholestatic picture (Alkaline phosphatase 898 IU/L, ALAT 194 IU/L, ASAT 234, үGT $464 \mathrm{IU} / \mathrm{L}$, total bilirubin $80 \mathrm{mg} / \mathrm{L}$ and conjugated bilirubin $68 \mathrm{mg} / \mathrm{L}$ ). Contrast enhanced computed tomography (CT) of the abdomen showed a locally advanced tissue density pancreatic mass measuring $15.6 \mathrm{~cm}$ in the larger diameter (Figure 1). A multidisciplinary reunion concluded to the non-feasibility of a surgical resection. An endoscopic drainage was planned but the patient underwent a radiological embolization first due to an intern hemorrhage. A biopsy of the pancreatic mass was performed. The microscopy and the immuno-profile were suggestive of a renal cell carcinoma (Figure 2). In March 2016 and after normalization of laboratory tests, the patient was commenced on everolimus as a second line of a palliative strategy. After three months of treatment, the patient had a stable disease, but the alteration of his performance status and multifactorial anemia forced us to suspend the drug and to undergo numerous blood transfusions. The patient was on exclusive palliative care for three months before his death.

\section{Discussion}

RCC is a common cancer type. When the tumor is limited and remains in stage 1 , it is characterized by a high 5-year survival rate (up to 95\%) [6]. However, once it develops widespread metastases, the 5-year survival rate of the patients will drop to less than 10\% [7]. Pancreatic metastasis accounts for $2 \%-5 \%$ of pancreatic malignancies. However, it seems to be related to a relatively good prognosis and leads to a different therapy strategy [8]. Therefore, it is very important to preoperatively diagnose a pancreatic metastasis. Solitary pancreatic metastases are difficult to differentiate and may be misdiagnosed as primary pancreatic cancer.

Due to their rarity and peculiarity, pancreatic metastases of RCC were described mostly in case reports. In 2006, Sellner and colleagues [9] conducted a high volume systemic research which thoroughly reviewed the literature of RCC with pancreatic metastasis from 1952 to 2003. Jing Dong and colleagues [10] 
Table 1. Sociodemographic and clinical characteristics of the patient.

\begin{tabular}{cccc}
\hline Patient characteristics & Age & Gender & Origin \\
\hline \multirow{2}{*}{ Antecedent } & 50 & Male & North African \\
& Patient & & Family \\
& Obesity & & No history of cancer \\
\hline
\end{tabular}

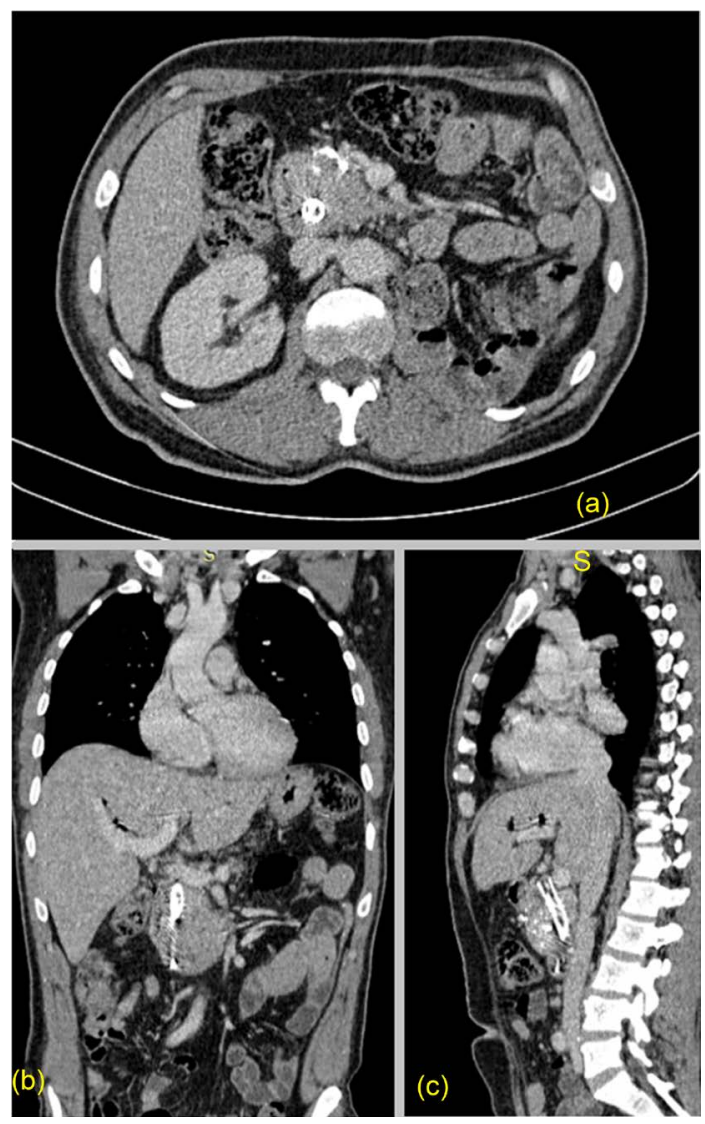

Figure 1. Scannographic axial (a) coronal (b) and sagittal (c) sections of a pancreatic mass.

compared a series of 7 cases to a systematic review to conclude that asymptomatic metastases and surgical procedures were independent factors associated with better survival.

In our case, the patient was non-operable and a new line of targeted therapy was the best available option.

Data suggests that RCC with pancreatic metastasis have a better outcome than lymph nodes, liver or cerebral metastasis [11] [12]. The overall survival rates are $80.6 \%$ and $72.6 \%$ at 2 and 5 years for resected patients versus 41 and $14 \%$ respectively in unresected patients [13].

\section{Conclusion}

In conclusion, when pancreatic metastases of RCC are resectable, surgical treatment might be an option as long as no comorbidity contraindicates resection. The optimal resection strategy involves adequate resection margins and 


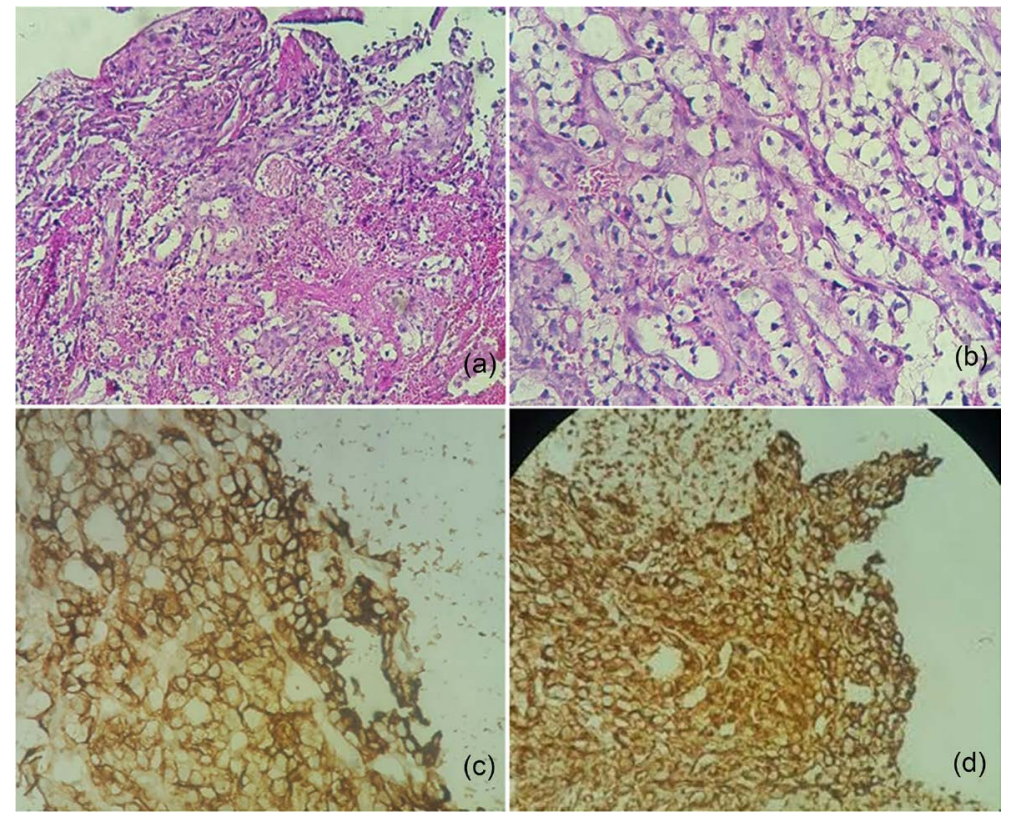

Figure 2. Pancreatic metastasis of a RCC [H \& E $\times 100$ (a) H \& E $\times 400$ (b)], tumor cell positive for $\mathrm{CD} 10$ (c) and vimentine (d) and negative for $\mathrm{CK}$.

maximal tissue preservation of the pancreas. If surgery is impossible, all palliative options (radiological, endoscopic and systemic treatment) should be deployed to improve symptoms and the quality of life.

\section{References}

[1] American Cancer Society (2014) Cancer Facts \& Figures 2014. American Cancer Society, Atlanta.

[2] Roland, C.F. and Van Heerden, J.A. (1989) Non Pancreatic Primary Tumors with Metastasis to the Pancreas. Surgery, Gynecology \& Obstetrics, 168, 345-347.

[3] Faure, J.P., Tuech, J.J., Richer, J.P., Pessaux, P., Arnaud, J.P. and Carretier, M. (2001) Pancreatic Metastasis of Renal Cell Carcinoma: Presentation, Treatment and Survival. The Journal of Urology, 165, 20-22. https://doi.org/10.1097/00005392-200101000-00005

[4] Skinner, D.G., Colvin, R.B., Vermillion, C.D., Pfister, R.C. and Leadbetter, W.F. (1971) Diagnosis and Management of Renal Cell Carcinoma A Clinical and Pathologic Study of 309 Cases. Cancer, 28, 1165-1177. https://doi.org/10.1002/1097-0142(1971)28:5<1165::AID-CNCR2820280513>3.0.C $\underline{\mathrm{O} ; 2-\mathrm{G}}$

[5] Ritchie, A.W. and Chisholm, G.D. (1983) The Natural History of Renal Carcinoma. Seminars in Oncology, 10, 390-400.

[6] Pantuck, A.J., Zisman, A. and Belldegrun, A.S. (2001) The Changing Natural History of Renal Cell Carcinoma. The Journal of Urology, 166, 1611-1623. https://doi.org/10.1016/S0022-5347(05)65640-6

[7] Janzen, N.K., Kim, H.L., Figlin, R.A. and Belldegrun, A.S. (2003) Surveillance after Radical or Partial Nephrectomy for Localized Renal Cell Carcinoma and Management of Recurrent Disease. Urologic Clinics, 30, 843-852. https://doi.org/10.1016/S0094-0143(03)00056-9

[8] Thompson, L.D. and Heffess, C.S. (2000) Renal Cell Carcinoma to the Pancreas in 
Surgical Pathology Material. Cancer, 89, 1076-1088.

https://doi.org/10.1002/1097-0142(20000901)89:5<1076::AID-CNCR17>3.0.CO;2M

[9] Sellner, F., Tykalsky, N., De Santis, M., Pont, J. and Klimpfinger, M. (2006) Solitary and Multiple Isolated Metastases of Clear Cell Renal Carcinoma to the Pancreas: An Indication for Pancreatic Surgery. Annals of Surgical Oncology, 13, 75-85. https://doi.org/10.1245/ASO.2006.03.064

[10] Dong, J., Cong, L., Zhang, T.P. and Zhao, Y.P. (2016) Pancreatic Metastasis of Renal Cell Carcinoma. Hepatobiliary \& Pancreatic Diseases International, 15, 30-38. https://doi.org/10.1016/S1499-3872(16)60052-8

[11] Kalra, S., Atkinson, B.J., Matrana, M.R., Matin, S.F., Wood, C.G., Karam, J.A., et al. (2015) Prognosis of Patients with Metastatic Renal Cell Carcinoma and Pancreatic Metastases. BJU International, 117, 761-765. https://doi.org/10.1111/bju.13185

[12] Santoni, M., Conti, A., Porta, C., Procopio, G., Sternberg, C.N., Basso, U., et al. (2015) Sunitinib, Pazopanib or Sorafenib for the Treatment of Patients with Late Relapsing Metastatic Renal Cell Carcinoma. The Journal of Urology, 193, 41-47. https://doi.org/10.1016/j.juro.2014.07.011

[13] Tanis, P.J., Van der Gaag, N.A., Busch, O.R.C., Van Gulik, T.M. and Gouma, D.J. (2009) Systematic Review of Pancreatic Surgery for Metastatic Renal Cell Carcinoma. British Journal of Surgery, 96, 579-592. https://doi.org/10.1002/bjs.6606

\section{Submit or recommend next manuscript to SCIRP and we will provide best service for you:}

Accepting pre-submission inquiries through Email, Facebook, LinkedIn, Twitter, etc. A wide selection of journals (inclusive of 9 subjects, more than 200 journals) Providing 24-hour high-quality service User-friendly online submission system Fair and swift peer-review system Efficient typesetting and proofreading procedure Display of the result of downloads and visits, as well as the number of cited articles Maximum dissemination of your research work

Submit your manuscript at: http://papersubmission.scirp.org/

Or contact jct@scirp.org 